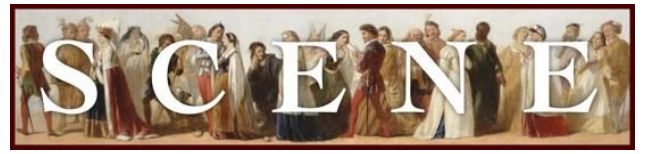

\title{
"Mercutio, thou consortest [a bit too much] with Romeo"
}

by Kevin Quarmby. Written on 2017-10-21. Published in 2017 Issue 2.

For the production: Romeo and Juliet (2017, Guthrie Theater, USA). See production details at the end of the review.

The Wurtele Thrust Stage of the Minneapolis Guthrie Theater is transformed into a Disneyesque Italian mountaintop village scene, designed with film-set care by Anna Louizos. In the extensive production notes, Louizos states that she is consciously evoking walled isolation and generational civil conflict. The resulting set conjures a visual image of a "restrictive and repressive world" with unusually precise materiality. This microcosmic Verona, complete with walled stairways, towering medieval window-lit dwellings, and a clock and bell tower that looms as the central menacing symbol of power, offers a National Geographic specificity to Joseph Haj's Romeo and Juliet.

Constructed on the Wurtele's revolve, the town rotates in tandem with the clock-face dials to reveal a meticulous pre-Raphaelite Juliet bedchamber, a ubiquitous stone balcony, or Friar Lawrence's monastic chambers. The central acting area is dominated at first by a practical fontshaped fountain that gently mushrooms in watery realism. Trapdoor mechanisms allow this fountain to fall beneath the stage, leaving behind a hexagonal, slightly-raised platform which eventually accommodates the resting-place tomb of Juliet. Three lower-level doors are located in the set, though these seem only incidental since most entrances and exits occur through the downstage right and left audience access points.

If the Guthrie Theater's Romeo and Juliet appears pre-Raphaelite in it perspectival verisimilitude, then it becomes decidedly postmodern in its directorial conceit. Bill McCallum's prologuing Chorus enters in grey twenty-first-century office-worker suit and tie, which hints at his subsequent status as Prince of Verona. Soon the stage is peopled with the warring Capulet/Montague factions, represented by the endearingly comic Potpan of Corey Farrell and his cohort, who clash swords with Balthazar and his ilk. Costumed by Jennifer Moeller, these young swaggerers are grunge-like post-punk pseudo-anarchists, their tattooed bodies, and clothing reminiscent of Occupy Wall Street unrest and revolutionary zeal. 


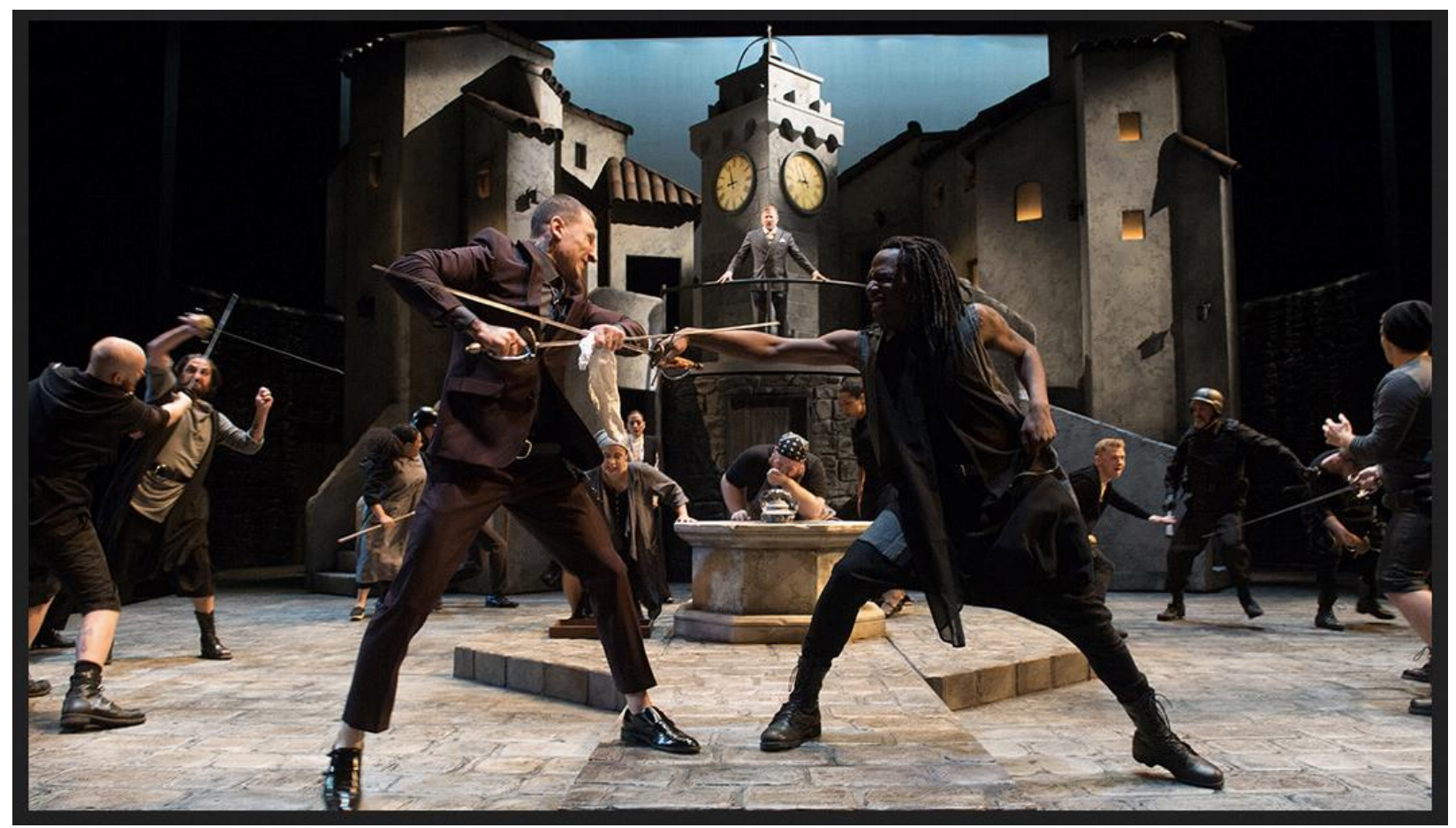

Figure 1: Stan Demidoff (Tybalt) locks swords with Lamar Jefferson (Benvolio) in the foreground of Romeo and Juliet. Photo by Jenny Graham.

Postmodernism even extends to the family structures. Romeo is now the single-parent child of the sword-wielding matriarch Lady Montague of Charity Jones, his mother more menacing than some of the youthful aggressors who beat heads and slash at bodies only to be dispersed by less convincing riot-gear-clad policing supernumeraries. Lord and Lady Capulet remain, though the timeless feud between the families seems oddly nuanced with the loss of a Montague patriarchal role. This generic clash, which highlights the inherent comedy of play, only elevates Candace Barrett Birk's Nurse to a comic tour de force. There is something quaintly reassuring to see how little one need (or can) alter the Nurse's character when modifying Romeo and Juliet's narrative appeal.

Even more unusual, and decidedly more confusing, is the gender-blind casting of Kelsey Didion as a lithesome, sexually-charged Mercutio, content to flaunt her tattooed bare-fleshed body at Romeo with barely-disguised sensual glee. Never did Tybalt's 3.1 accusatory attack, "Mercutio, thou consortest with Romeo," seem more apt. Didion's eroticized tomboyism offers little by way of narrative explanation for the Romeo/Mercutio relationship other than unrequited sexual frustration.

As Romeo, Ryan-James Hatanaka makes light work of the youthful flightiness of this teenage lust machine. When distraught at being banished, Hatanaka buries his head in his hands and grieves at the loss of his Juliet. The juvenility of Romeo is heightened, however, by the character 
creation of Kate Eastman, whose Juliet received appreciative vocal support from younger members of the audience. When Romeo attempts unsuccessfully to scale the balcony to his love, his legs are left dangling in impotent bicycling motion. This Romeo lacks the traditional macho attributes of dexterity and strength. Juliet is forced to run down to stage level to meet her love. As the lovers part and Juliet needs swiftly to reenter her bedchamber window, she effortlessly clambers up the steep walls to her balcony, her departure greeted with laughter and knowing applause.

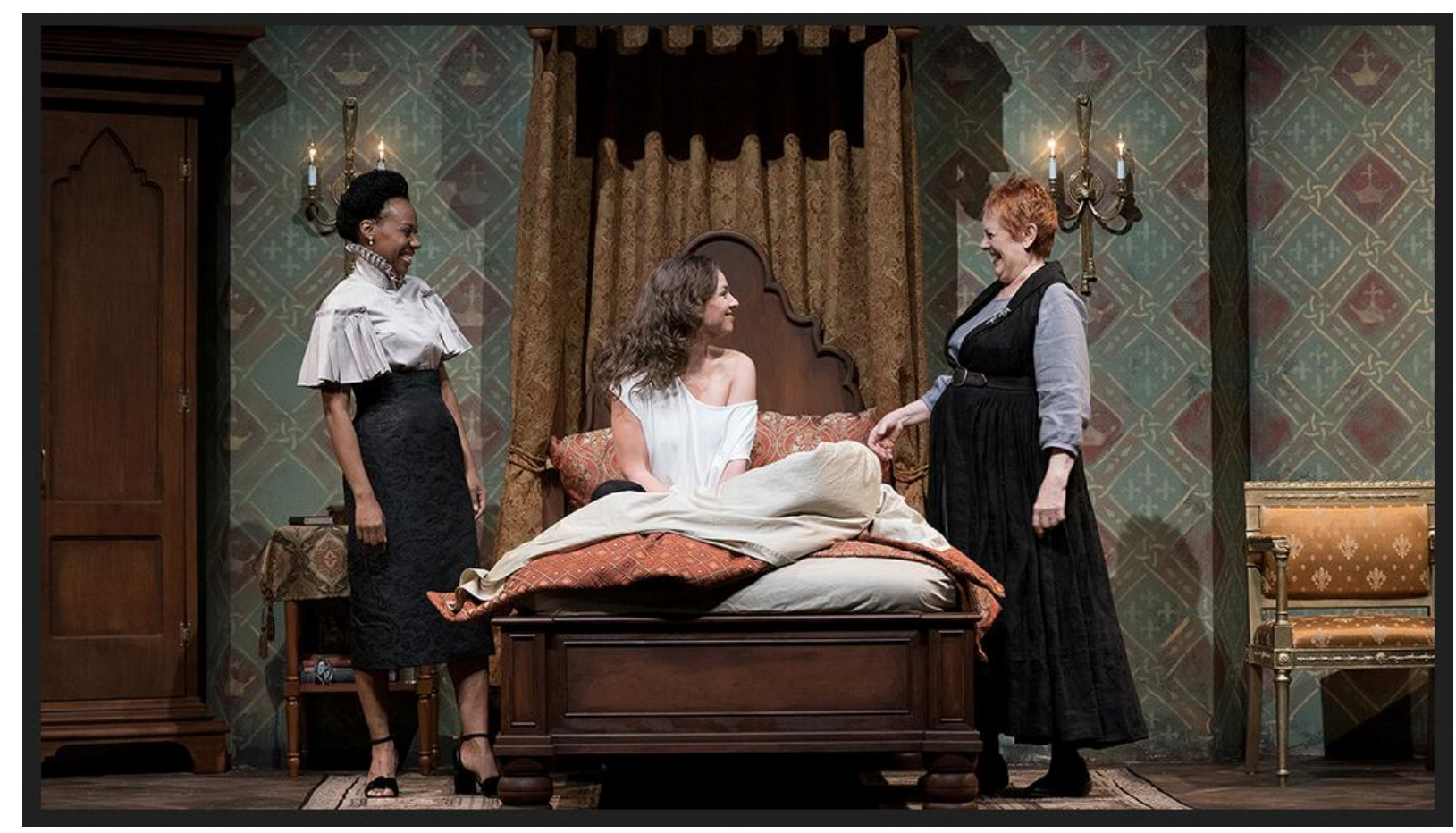

Figure 2: Shá Cage (Lady Capulet), Kate Eastman (Juliet) and Candace Barrett Birk (Nurse) in Romeo and Juliet. Photo by Jenny Graham.

With color-blind casting the norm for any self-respecting twenty-first-century Shakespeare company, it is no surprise that the Lady Capulet of Shá Cage should manifest as a stylish African American, or that Friar Lawrence should be deftly presented by the sympathetic James A. Williams. What might be surprising, however, is why the attractive Lady Capulet should bother with the less dynamic Lord Capulet of Andrew Weems, whose "young baggage" and "disobedient wretch" attack suggested weak petulance rather than patriarchal malice. At no time did we really feel that Juliet was shocked by these paternal outbursts, which lacked dynamic malevolence. She had heard this so many times before. Just another of her father's outpourings of self-loathing at his own middle-class, grey-suited mundanity, the attack on Juliet passed as a predictably annoying segue into the tragedy that followed. 
With an overall running time of two hours and thirty-five minutes and some extensive cutting of the script, Joseph Haj's production offers a clear and paced romp through the Romeo and Juliet narrative. With the conflation of 3.2 with 3.3, whereby Romeo and Lawrence share the stage with Juliet and the Nurse and the young lovers' respective outbursts mirror each other like a star-cross'd tennis match, the production invokes the split-scene pacing of a Netflix miniseries. The Guthrie Romeo and Juliet might be heralded with a "Content Advisory" trigger warning about its "many physical and verbal jokes and puns (some sexual in nature), moments of swordplay and violence, modestly attired characters, and an iconic final scene when the young lovers take their own lives," but Joseph Haj deftly adds a smattering of contemporary political commentary to a production that obviously appeals to many, while potentially confusing a few.

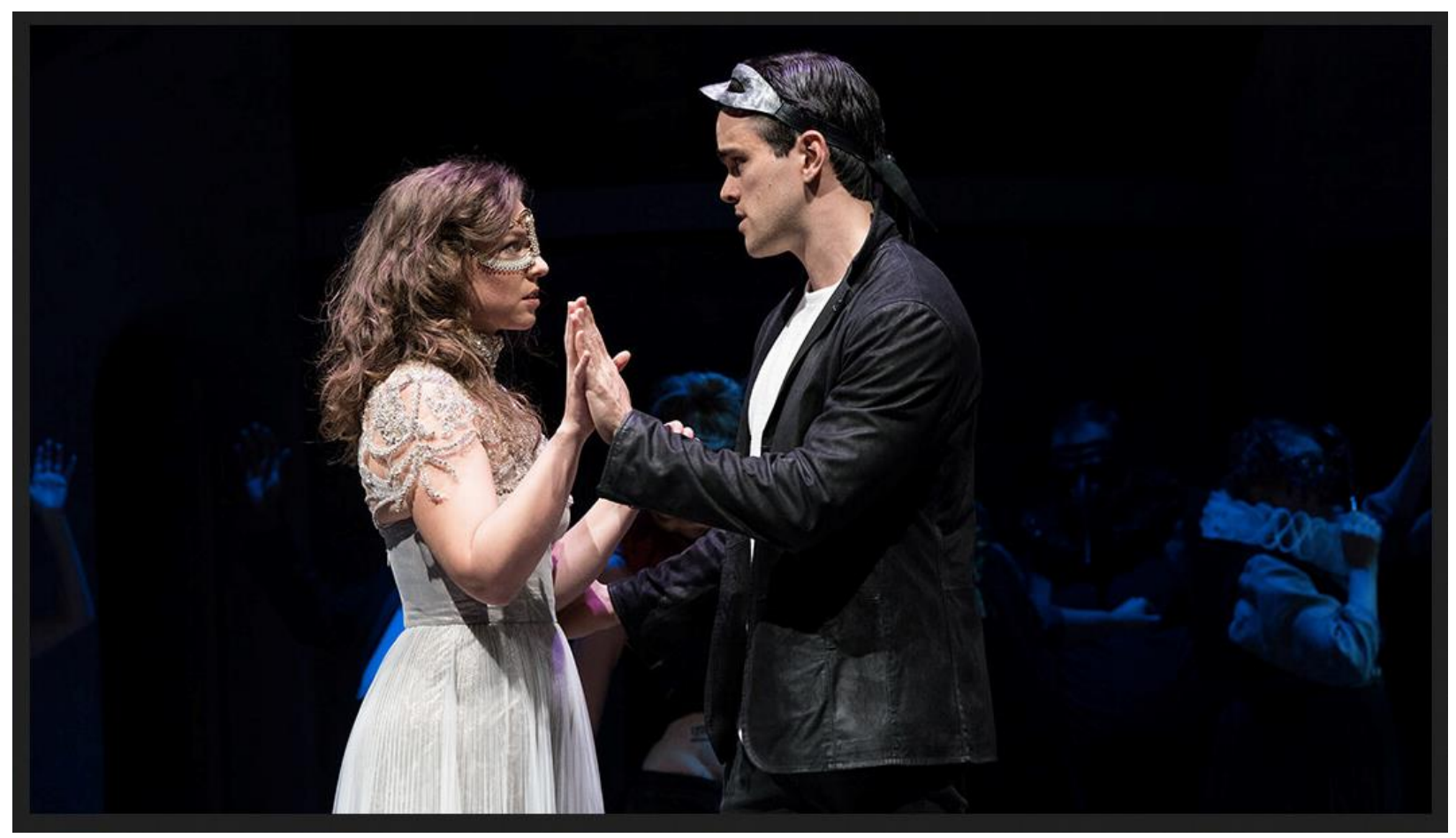

Figure 3: Kate Eastman (Juliet) and Ryan-James Hatanaka (Romeo) in Romeo and Juliet. Photo by Jenny Graham.

\section{Production Details}

\section{General}

Title

Romeo and Juliet

Year 2017

Theater Company Guthrie Theater

Theaters Guthrie Theater (USA) 
$\begin{array}{ll}\text { Start Date } & \text { 2017-09-09 } \\ \text { End Date } & 2017-10-28\end{array}$

\section{Cast}

\begin{tabular}{|c|c|}
\hline Romeo Montague & RYAN-JAMES HATANAKA \\
\hline Juliet CAPUlET & Kate EAstman \\
\hline Prince Escalus & BILl MCCALLUM \\
\hline PARIS & JOHN CATRON \\
\hline LADY MONTAGUE & CHARITY JONES \\
\hline LADY CAPULET & SHÁ CAGE \\
\hline Capulet & ANDREW WEEMS \\
\hline NURSE & CANDACE BARRETT BIRK \\
\hline MERCUTIO & KELSEY DIDION \\
\hline BenVOLIO & LAMAR JEFFERSON \\
\hline TyBaLT & STAN DEMIDOFF \\
\hline FRIAR LAWRENCE & JAMES A. Williams \\
\hline FRIAR JOHN & DAMIAN LEVERETT \\
\hline BALTHASAR & JASON A. ROJAS \\
\hline REGORY & DAMIAN LEVERETT \\
\hline IGE TO PARIS & COREY FARRELL \\
\hline POTHECARY & STAN DEMIDOFF \\
\hline
\end{tabular}

\section{Creatives}

$\begin{array}{ll}\text { Artistic Director } & \text { Joseph Haj } \\ \text { Costume Designer } & \text { JenNifer Moeller } \\ \text { SCenic Designer } & \text { AnNA Louizos } \\ \text { Lighting Designer } & \text { JOsh Epstein } \\ \text { SOUnd Designer } & \text { Vincent Olivieri } \\ \text { Composer } & \text { Victor Zupanc }\end{array}$

